\title{
Association between childhood community safety interventions and hospital injury records: a multilevel study
}

\author{
E Sellström, K Guldbrandsson, S Bremberg, A Hjern, G Arnoldsson
}

See end of article for authors' affiliations

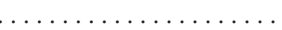

Correspondence to: Eva Sellström, MidSweden University, Department of

Nursing and Health

Sciences, SE-831 25

Östersund, Sweden;

eva.sellstrom@mh.se

Accepted for publication 5 February 2003
Study objective: To study municipal variations in children's injury risk and to assess the impact of safety promotion measures in general municipal, preschool, school, and leisure activity settings, on injury outcome.

Design: A cohort study based on individual data on children's consumption of hospital care as a result of injury, the age and sex of each child, and socioeconomic data on each child's mother. Municipal characteristics - that is, population density and municipal safety measures - were also used. Connections between individual and community level determinants were analysed with multilevel logistic regression.

Setting: Twenty five municipalities in Stockholm County in Sweden were studied.

Participants: Children between 1 and 15 years old in 25 municipalities in Stockholm County, identified in the Total Population Register in Sweden. The study base included 1055179 person years.

Main results: Municipality injury rates varied between 3.84-7.69 per 1000 person years among 1-6 year olds and, between 0.86-6.18 among 7-15 year olds. Implementation of multiple safety measures in a municipality had a significant effect on the risk of injury for preschool children. In municipalities that implemented few safety measures, the risk of injury was 33\% higher than in municipalities that implemented many. A similar effect, though insignificant, was observed in the school aged children. Conclusions: This study shows that how municipalities organise their safety activities affect injury rates. Sweden has a comparatively low injury rate and thus, in a European perspective, there is an obvious potential for municipal safety efforts.
O ver the past 10 to 20 years, cross sectorial injury prevention programmes-community intervention programmes - aimed at reducing the number of childhood injuries have been implemented in several countries. ${ }^{1-5} \mathrm{~A}$ community intervention programme can be understood as an attempt to integrate a municipality's efforts to prevent non-intentional injuries, as compared with having separate sectors-such as traffic, school, and childcare-work independently. Thus, interaction between sectors within the municipality is believed to be crucial for the effectiveness of a community intervention programme. In a study of safety measures in Swedish municipalities, Guldbrandsson and Bremberg have proved that interactions do occur between different municipal sectors (unpublished data). The World Health Organisation (WHO) has developed a model for community intervention programmes within safety promotion: Safe Communities. This model draws on injury registration, cross sectorial cooperation, and the integration of safety promotive measures within the municipality in order to create a safer environment. Children and adolescents form an important target group for such programmes. The empirical support for this approach is still disputed. In two reviews of the effects of community intervention programmes emphasising safety promotion for children and adolescents, the authors do not find evidence that such programmes are effective. ${ }^{78}$ However, in a recent review, Towner and Dowswell examined 10 community based injury prevention interventions and concluded that there is some evidence for the effectiveness of such interventions. ${ }^{9}$ Yet, the issue is still not settled.

Evaluating community intervention programmes is complex in terms of methodology. To perform experimental studies, which would be the optimum, where whole communities are randomly assigned to control and intervention groups, entail a number of practical difficulties, including cost and feasibility limitations. Thus, such studies have not been performed. Instead, "before and after" studies in single communities have been carried out, either without any controls or with another community serving as a control. ${ }^{7-9}$ Considering the limitations of these experimental studies, an observation design might present an attractive option as that would permit analysis of a larger number of municipalities.

In this study, a multilevel design was used to clarify how municipal safety measures, after controlling for individual and community risk factors, might influence children's and adolescents' risk of being admitted to hospital because of injury.

\section{METHODS \\ Population}

The study population consisted of all children between the ages 1 and 15 who were residents in one of 25 municipalities in Stockholm County (excluding the city of Stockholm) on the 31 of December 1994, 1995, 1996, 1997, and/or 1998, according to the Total Population Register. ${ }^{10}$ Stockholm city was excluded because its size, 0.8 million inhabitants, made it difficult to compare activities in this city with activities in the remaining 25 municipalities, with an average 40000 inhabitants. Each child was followed up one year from those dates, and the study base thus included 1056064 person years: 450481 person years of children between the ages of 1 and 6 , and 605583 person years of children between the ages of 7 and 15 .

\section{Design and variables}

This study was based on Swedish national registers held by the Swedish Board on Health and Welfare and Statistics 
Table 1 Safety promotive measures in municipality setting in general, in 25 municipalities in Stockholm County

\begin{tabular}{|c|c|c|c|}
\hline Aspect assessed & $\begin{array}{l}\text { Questions covering safety promotive measures in municipality setting in } \\
\text { general (answers and their coding) }\end{array}$ & $\begin{array}{l}\text { Number of } \\
\text { municipalities with an } \\
\text { original score }>0.00\end{array}$ & $\begin{array}{l}\text { Range of } \\
\text { standardised } \\
\text { scores }\end{array}$ \\
\hline \multirow[t]{3}{*}{ Injury registration } & $\begin{array}{l}\text { Do the municipality get information about injuries to children from the health } \\
\text { care sector? }(Y e s=1.00, \text { no=0.00) }\end{array}$ & 6 & $0-4.17$ \\
\hline & $\begin{array}{l}\text { How often does the municipality get information? (Once a month }=1.00 \text {, once } \\
\text { every six months }=0.75 \text {, once a year }=0.50 \text {, more seldom }=0.25 \text { ) }\end{array}$ & 4 & $0-11.11$ \\
\hline & $\begin{array}{l}\text { How is information about injuries to children used? (Preventive measures are } \\
\text { taken }=1.00 \text {, no preventive measures are taken }=0.00 \text { ) }\end{array}$ & 6 & $0-4.17$ \\
\hline \multirow[t]{4}{*}{ Intersectorial groups } & $\begin{array}{l}\text { Do representatives from different sectors in society meet to discuss injury } \\
\text { prevention? }(Y e s=1.00, \text { no }=0.00)\end{array}$ & 12 & $0-2.08$ \\
\hline & $\begin{array}{l}\text { What municipal sectors are represented? }(5 \text { or more representatives } \\
\text { listed }=1.00,1-4 \text { representatives listed }=0.50 \text {, no representatives listed }=0.00 \text { ) }\end{array}$ & 11 & $0-3.13$ \\
\hline & Is the health care sector represented? $(Y e s=1.00, \mathrm{no}=0.00)$ & 4 & $0-6.25$ \\
\hline & $\begin{array}{l}\text { How often does the group meet? (Once a month }=1.00 \text {, once every second } \\
\text { month }=0,75 \text {, once every sixth months }=0.50 \text {, once a year }=0.25 \text {, more } \\
\text { seldom }=0.00 \text { ) }\end{array}$ & 9 & $0-4.76$ \\
\hline \multirow[t]{2}{*}{ General policy } & $\begin{array}{l}\text { Does the municipality have an injury preventive programme or policy for all } \\
\text { children and adolescents in the municipality? (Yes }=1.00, \mathrm{no}=0.00 \text { ) }\end{array}$ & 5 & $0-5.00$ \\
\hline & $\begin{array}{l}\text { Has the municipality produced an injury preventive programme or policy in } \\
\text { cooperation with another sector in society, for example, the heath care sector? } \\
(\text { Yes }=1.00, \mathrm{no}=0.00 \text { ) }\end{array}$ & 4 & $0-6.25$ \\
\hline Total municipality setting in general & Sum of scores on all questions above & $14 / 25$ & $0-3.69$ \\
\hline
\end{tabular}

Sweden linked through each individual's unique civic registration number. ${ }^{10-16}$ Twenty five municipalities of Stockholm County were included in the study. These municipalities were chosen as data collection on municipal safety measures was restricted to this region. The municipal level was chosen as municipalities in Sweden are responsible for the largest part of children's environments, playgrounds, day care, schools and many sports and other leisure activities. The study was based on individual data on children's consumption of hospital care as a result of injury, the age and sex of each child, and socioeconomic data on each child's mother. Municipal characteristics-that is, population density and municipal safety measures-were also used. Individual and ecological data were linked via a geographical code for the municipality.

\section{Outcome variable}

Data on injuries among children aged 1 to 15 were obtained from the Hospital Discharge Register, 1995 to 1999, where all injuries resulting in hospitalisation were registered. ${ }^{11}$ The collection of data was restricted to one injury per person year. This restriction was implemented because severely injured children can be discharged from and admitted to different clinics, thereby ending up in the register several times for the same injury. Injuries were defined as injuries falling within the range of E830-E929 in ICD-9 or W 01-X 59 in ICD-10. ${ }^{12}{ }^{13}$ Transportation related injuries were not analysed in this study.

\section{Individual level determinants}

The mothers of the children in the study were identified using the Multi-generation Register. ${ }^{14}$ The study distinguished between mothers born in Sweden $(=0)$ and those born elsewhere $(=1)$. Data on mothers' educational backgrounds were obtained from Sweden's Education Register the year before the year of study, and coded such that $\mathrm{l}=$ university/ college educated, $2=$ three to four years of secondary school, $3=$ two years of secondary school, or primary school only. ${ }^{15}$

Table 2 Safety promotive measures in preschool settings, in 25 municipalities in Stockholm County

\begin{tabular}{|c|c|c|c|}
\hline Aspect assessed & $\begin{array}{l}\text { Questions covering safety promotive measures in preschool setting. } \\
\text { (answers and their coding) }\end{array}$ & $\begin{array}{l}\text { Number of } \\
\text { municipalities with } \\
\text { a score }>0.00\end{array}$ & $\begin{array}{l}\text { Range of } \\
\text { standardised } \\
\text { scores }\end{array}$ \\
\hline \multirow[t]{5}{*}{ Places for play } & $\begin{array}{l}\text { What surface (or surfaces) are found on the playgrounds and preschool yards in the } \\
\text { municipality }(76-100 \% \text { sand }=1.00,51-75 \% \text { sand }=0.75,26-50 \% \text { sand }=0.50,1-25 \% \\
\text { sand }=0.25 \text {, no sand }=0.00 \text { ) }\end{array}$ & 21 & $0.51-2.05$ \\
\hline & $\begin{array}{l}\text { How often are the municipality playgrounds and preschool gardens maintained? (Every } \\
\text { month }=1.00 \text {, every six months }=0.50 \text {, every year }=0.20 \text {, no maintaining measures }=0.00 \text { ) }\end{array}$ & 20 & $0.34-1.72$ \\
\hline & $\begin{array}{l}\text { How often are playgrounds safety rounds performed? (Once a month }=1.00 \text {, once every six } \\
\text { months }=0.50 \text {, once a year }=0.20 \text {, no safety rounds }=0.00)\end{array}$ & 22 & $0.59-2.93$ \\
\hline & $\begin{array}{l}\text { How often are preschool safety rounds performed outdoors? (Once a month }=1.00 \text {, once } \\
\text { every six months }=0.50 \text {, once a year }=0.20 \text {, no safety rounds }=0.00 \text { ) }\end{array}$ & 21 & $0.51-2.56$ \\
\hline & $\begin{array}{l}\text { How often are preschool safety rounds performed indoors? (Once a month }=1.00 \text {, once } \\
\text { every six months }=0.50 \text {, once a year }=0.20 \text {, no safety rounds }=0.00 \text { ) }\end{array}$ & 23 & $0-3.20$ \\
\hline \multirow[t]{3}{*}{ Injury registration } & Does any preschool in the municipality have local injury registration? $(Y e s=1.00$, no $=0.00)$ & 15 & $0-1.67$ \\
\hline & $\begin{array}{l}\text { Percentages of preschools in the municipality with local injury registration? } \\
(76-100 \%=1.00,51-75 \%=0.75,26-50 \%=0.50,1-25 \%=0.25)\end{array}$ & 12 & $0-2.15$ \\
\hline & $\begin{array}{l}\text { How is locally registered injury information used? (Preventive measures are taken }=1.00 \text {, no } \\
\text { preventive measures are taken }=0.00 \text { ) }\end{array}$ & 15 & $0-1.67$ \\
\hline \multirow[t]{2}{*}{ Safety training } & Does the municipality have a plan for staff safety training? $(Y e s=1.00$, no=0.00) & 5 & $0-4.2$ \\
\hline & $\begin{array}{l}\text { How often is preschool staff in the municipality offered education in childhood injury } \\
\text { prevention? (Once every six months }=1.00 \text {, once a year }=0.50 \text {, more seldom }=0.25 \text {, } \\
\text { never }=0.00 \text { ) }\end{array}$ & 16 & $0-2.73$ \\
\hline Total preschool setting & Sum of scores on all questions above & $25 / 25$ & $0.10-1.65$ \\
\hline
\end{tabular}


Table 3 Safety promotive measures school leisure activity settings, in 25 municipalities in Stockholm County

\begin{tabular}{|c|c|c|c|}
\hline Aspect assessed & $\begin{array}{l}\text { Questions covering safety promotive measures in school leisure activity } \\
\text { settings. (answers and their coding) }\end{array}$ & $\begin{array}{l}\text { Number of } \\
\text { municipalities with an } \\
\text { original score }>0.00\end{array}$ & $\begin{array}{l}\text { Range of } \\
\text { standardised } \\
\text { scores }\end{array}$ \\
\hline Playground surface & $\begin{array}{l}\text { What surface (or surfaces) are found on the playgrounds and school yards in } \\
\text { the municipality }(76-100 \% \text { sand }=1.00,51-75 \% \text { sand }=0.75,26-50 \% \\
\text { sand }=0.50,1-25 \% \text { sand }=0.25 \text {, no sand }=0.00 \text { ) }\end{array}$ & 24 & $0.67-2.67$ \\
\hline Swimming training & $\begin{array}{l}\text { Does the municipality offer swimming training to the pupils? (Yes=1.00, } \\
n o=0.00 \text { ) }\end{array}$ & 24 & $0-1.04$ \\
\hline \multirow[t]{5}{*}{ Injury registration } & $\begin{array}{l}\text { Does any school in the municipality have local injury registration? (Yes=1.00, } \\
n 0=0.00)\end{array}$ & 21 & $0-1.19$ \\
\hline & $\begin{array}{l}\text { Percentages of schools in the municipality with local injury registration? } \\
(76-100 \%=1.00,51-75 \%=0.75,26-50 \%=0.50,1-25 \%=0.25)\end{array}$ & 19 & $0-1.30$ \\
\hline & $\begin{array}{l}\text { How is locally registered school injury information used? (Preventive measures } \\
\text { are taken }=1.00 \text {, no preventive measures are taken }=0.00 \text { ) }\end{array}$ & 20 & $0-1.05$ \\
\hline & $\begin{array}{l}\text { Does any municipal youth recreation centre or similar have local injury } \\
\text { registration? (Yes }=1.00, n o=0.00 \text { ) }\end{array}$ & 8 & $0-3.13$ \\
\hline & $\begin{array}{l}\text { How is information on registered injuries in youth recreation centres or similar } \\
\text { used? (Preventive measures are taken }=1.00 \text {, no preventive measures are } \\
\text { taken }=0.00 \text { ) }\end{array}$ & 7 & $0-3.57$ \\
\hline \multirow[t]{2}{*}{ Safety training } & $\begin{array}{l}\text { Does the municipality have a plan for students' safety training? (Yes=1.00, } \\
\text { no }=0.00 \text { ) }\end{array}$ & 9 & $0-2.57$ \\
\hline & $\begin{array}{l}\text { Does the municipality have a plan for staff safety training? (Yes=1.00, } \\
\text { no }=0.00)\end{array}$ & 5 & $0-4.60$ \\
\hline Total school leisure activity setting & Sum of scores on all questions above & $25 / 25$ & $0.26-1.66$ \\
\hline
\end{tabular}

Data regarding social allowance were identified in the Total Enumeration Income Survey the year before the year of study and sorted into two categories: those who received social allowance $(\operatorname{coded}=1)$ and those who did not $(\operatorname{coded}=0) .{ }^{16}$

\section{Community level determinants}

Data on each municipality's degree of urbanisation were obtained from Statistics Sweden and were based on data on the "fraction of population in sparsely populated areas". ${ }^{17}$

Variables describing the occurrence of municipal evidence based safety promotive efforts were also used. Evidence based safety measures were mainly identified from seven reviews. ${ }^{7}{ }^{18-22}$ An administrator in a supervisory position from each municipality was asked whether such measures were performed or not in the municipality during 1999-2001. Three settings were studied: the municipality setting in general, the preschool setting, and school/leisure activity settings. Traffic settings were not included in this study because of difficulties in obtaining valid data on safety measures in the traffic environment. In tables $1-3$ the safety measures used in the study are listed by the three separate settings.

The answer to each aspect was first given a preliminary score that ranged from 0 to 1 . Standardised scores were then computed for each separate question, for each setting, and for each municipality. The standardised score for each question was computed by dividing the preliminary score with the average score for each question. Standardised setting and municipality scores were computed by adding the separate question scores and dividing them with the average setting and municipality scores respectively. For analysis of 0-6 year old children, standardised scores were computed by combining the general municipality setting and the preschool setting scores, and for 7-15 year olds, the general municipality setting and the school/leisure setting scores were combined (see table $4)$.

\section{Statistical analyses}

Incidence ratios were calculated by municipality. Age standardisation was not relevant here because of the low number of cases in some of the small municipalities.

To investigate how individual level determinants were related to injury outcome, bivariate analyses were performed using logistic regression technique. ${ }^{23}$ The final phase in the statistical analysis involved multilevel logistic regression modelling. ${ }^{24}$ The conceptual basis for a two level model, as is used in this study, is that the effect (for example, the $\beta$ coefficient in regression) of individual level variables, in this study the child's age and the mother's receipt of social allowance, differs between level 2 units (in our case, between municipalities). The individual level determinants were intercorrelated and therefore "mother's receipt of social allowance" was chosen. Sex of child was not included in the multivariate models as we had no reason to believe that the boy:girl ratio would differ between municipalities. Three models were estimated for the age groups 1 to 6 year olds and 7 to 15 year olds respectively. The first model investigates the effect of safety measures controlling for the child's age. In the second model, individual level covariates are introduced, and the final model also controls for degree of urbanisation. As well as including main effects, all two way interactions were also explored in the

Table 4 Safety indices regarding 1- 6 year olds and 7-15 year olds, based on municipality setting in general and preschool setting and on municipality setting in general and school leisure setting respectively

\begin{tabular}{|c|c|c|c|c|c|c|}
\hline \multirow[b]{2}{*}{$\begin{array}{l}\text { Level of safety } \\
\text { measures }\end{array}$} & \multicolumn{3}{|c|}{ Safety index regarding $1-6$ year olds } & \multicolumn{3}{|c|}{ Safety index regarding $7-15$ year olds } \\
\hline & $\begin{array}{l}\text { Number of questions } \\
\text { with a code }>0\end{array}$ & Safety index & $\begin{array}{l}\text { Standardised } \\
\text { safety index }\end{array}$ & $\begin{array}{l}\text { Number of questions } \\
\text { with a code }>0\end{array}$ & Safety index & $\begin{array}{l}\text { Standardised } \\
\text { safety index }\end{array}$ \\
\hline Few & $2-8$ & $0.40-4.90$ & $0.07-0.82$ & $2-5$ & $1.25-4.50$ & $0.18-0.65$ \\
\hline Average & $9-10$ & $4.95-7.15$ & $0.83-1.20$ & $6-10$ & $5.25-8.50$ & $0.76-1.23$ \\
\hline Many & $10-18$ & $7.50-13.55$ & $1.26-2.27$ & $10-15$ & $8.75-14.00$ & $1.26-2.02$ \\
\hline
\end{tabular}




\begin{tabular}{|c|c|c|c|c|}
\hline \multirow[b]{2}{*}{ Municipality } & \multicolumn{2}{|c|}{$1-6$ year olds } & \multicolumn{2}{|c|}{$7-15$ year olds } \\
\hline & $\begin{array}{l}\text { Observed } \\
\text { person } \\
\text { years }\end{array}$ & $\begin{array}{l}\text { Injuries/1000 } \\
\text { person years }\end{array}$ & $\begin{array}{l}\text { Observed } \\
\text { person } \\
\text { years }\end{array}$ & $\begin{array}{l}\text { Injuries/1000 } \\
\text { person years }\end{array}$ \\
\hline A & 15504 & 4.77 & 21372 & 6.18 \\
\hline B & 11979 & 3.84 & 16104 & 4.72 \\
\hline C & 15454 & 5.69 & 21591 & 4.91 \\
\hline $\mathrm{E}$ & 14478 & 4.90 & 17372 & 5.47 \\
\hline D & 24568 & 3,99 & 34141 & 4.60 \\
\hline $\mathrm{F}$ & 10513 & 5.61 & 14774 & 6.16 \\
\hline G & 36640 & 6.30 & 48641 & 5.74 \\
\hline $\mathrm{H}$ & 33416 & 6.07 & 44764 & 5.74 \\
\hline 1 & 6453 & 6.66 & 8848 & 5.65 \\
\hline J & 30236 & 5.29 & 41768 & 5.82 \\
\hline K & 18370 & 4.84 & 23751 & 5.85 \\
\hline L & 9049 & 4.75 & 13223 & 6.20 \\
\hline M & 650 & 7.69 & 1158 & 0.86 \\
\hline $\mathrm{N}$ & 24862 & 4.06 & 35520 & 4.93 \\
\hline 0 & 11508 & 5.56 & 16177 & 5.75 \\
\hline$P$ & 25762 & 3.96 & 33983 & 5.21 \\
\hline Q & 34422 & 5.00 & 46220 & 4.20 \\
\hline R & 33466 & 4.69 & 41918 & 5.77 \\
\hline $\mathrm{s}$ & 11954 & 5.10 & 13529 & 4.29 \\
\hline T & 17648 & 6.06 & 19687 & 4.83 \\
\hline u & 14917 & 5.43 & 21278 & 5.17 \\
\hline V & 3859 & 5.70 & 5169 & 4.06 \\
\hline $\mathrm{x}$ & 19806 & 7.07 & 30522 & 6.29 \\
\hline Y & 15476 & 5.88 & 20109 & 4.92 \\
\hline Z & 9491 & 5.79 & 13964 & 5.23 \\
\hline Total & 450481 & 5.25 & 605583 & 5.35 \\
\hline
\end{tabular}

third model. Parameter estimates were derived using second order penalised quasi likelihood procedures (PQL). ${ }^{24}$ The statistical software package SAS (makro Glimmix) was used for the analyses. ${ }^{25}$ Random effects are represented by variance components $(\sigma)$. To assess the model's goodness of fit, AIC (Akaike's Information Criterion) is also presented in the models. ${ }^{26}$ AIC is the sum of the deviance and two times the number of parameters in the model so that the better fit is balanced by the increased complexity of a larger model (smaller is better).

\section{RESULTS}

In the study population observed, the overall rate of children 1 to 6 years old admitted to hospital for an injury was 5.25 per 1000 person years at risk, and of 7 to 15 year olds, 5.35 per
1000 person years at risk. Variation in injury risk by municipality and by age group is shown in table 5 .

In the bivariate analyses it became evident that in the younger age group children whose mothers received social allowance were at higher risk compared with children whose mothers did not receive social allowance. The odds ratio was 1.32. Likewise, children of mothers with a low education level, 11 years or less, were at higher risk compared with children of mothers with a university degree (see table 6).

Tables 7 and 8 present estimates obtained from the multilevel models. In table 7 determinants of injury to 1 to 6 year olds were investigated. In model 1 , a significant linear fixed effect of preschool and municipal safety measures on injury outcome was observed, controlling only for the child's age. Introduction of further individual and community level variables in models 2 and 3 as fixed effects did not change the estimate of safety measures obtained in model 1 . The individual level variable "mothers' receipt of social allowance" in model 2 reduced unexplained variability between municipalities. In this model, goodness of fit was also improved as AIC became smaller. Entering a community level variable, degree of urbanisation, in model 3 did not reduce unexplained variability. No interaction terms were significant and therefore none were included in model 3.

Regarding 7 to 15 year olds, safety measures in the municipality and in school/leisure activity settings had a small, though insignificant, effect on injury outcome with an OR of 1.09 ( see table 8). In model 1 , the child's age was significant in that the older the child, the greater the injury risk. As for 1 to 6 year olds, introduction of further individual and community level variables as fixed effects in models 2 and 3 did not change the estimate of safety measures obtained in model 1. Entering the individual level variable "mothers' receipt of social allowance" in model 2 resulted in lower AIC. A community level determinant, degree of urbanisation, was included in model 3. The variable had no significant effect. The model's unexplained variability increased and AIC remained practically unchanged. No interaction terms were significant and therefore none were included in model 3.

\section{DISCUSSION}

In this study we have demonstrated that a high level of safety measures in a municipality correlates with a low rate of hospital admissions for injuries in preschool children. A similar relation, although statistically insignificant, was observed in school aged children.

In Sweden there is an extensive national system for equalising municipal resources. Large variations in safety measures were accordingly not expected, either between the municipalities in Stockholm County, or between these municipalities and

\begin{tabular}{|c|c|c|}
\hline & \multicolumn{2}{|l|}{ OR $(95 \% \mathrm{Cl})$} \\
\hline & $1-6$ year olds & $7-15$ year olds \\
\hline \multicolumn{3}{|l|}{ Sex of child } \\
\hline Girl & 1.00 & 1.00 \\
\hline Boy & 1.35 (1.24 to 1.47$)$ & 1.83 (1.70 to 1.97$)$ \\
\hline \multicolumn{3}{|l|}{ Maternal education (y) } \\
\hline$>13$ & 1.00 & 1.00 \\
\hline $12-13$ & $1.00(0.91$ to 1.10$)$ & 1.04 (0.96 to 1.12 ) \\
\hline $0-11$ & 1.45 (1.29 to 1.63$)$ & 1.05 (0.95 to 1.16$)$ \\
\hline \multicolumn{3}{|l|}{ Country of birth of mother } \\
\hline Sweden & 1.00 & 1.00 \\
\hline Other country & 0.99 (0.90 to 1.09 ) & 0.97 (0.89 to 1.05$)$ \\
\hline \multicolumn{3}{|l|}{ Social allowance } \\
\hline Did not receive social allowance & 1.00 & 1.00 \\
\hline Received social allowance & 1.32 (1.18 to 1.47$)$ & 1.09 (0.98 to 1.21$)$ \\
\hline
\end{tabular}


Table 7 Differences in injury outcome in 1-6 year olds, explained by factors at the municipality level and by individual characteristics

\begin{tabular}{|c|c|c|c|c|c|c|}
\hline & \multicolumn{2}{|l|}{ Model 1} & \multicolumn{2}{|l|}{ Model 2} & \multicolumn{2}{|l|}{ Model 3} \\
\hline & $\beta$ value (SE) & OR $(95 \% \mathrm{Cl})$ & $\beta$ value (SE) & OR $(95 \% \mathrm{Cl})$ & $\beta$ value (SE) & OR $(95 \% \mathrm{Cl})$ \\
\hline \multicolumn{7}{|l|}{ Fixed effects } \\
\hline Intercept & \multicolumn{2}{|c|}{$-5.404^{* * *}(0.058)$} & \multicolumn{2}{|c|}{$-5.440 * * *(0.058)$} & \multicolumn{2}{|l|}{$-5.442 * * *$} \\
\hline Age & $0.003(0.012)$ & $1.00(0.98$ to 1.03$)$ & $0.003(0.012)$ & $1.00(0.98$ to 1.03$)$ & $0.003(0.012)$ & $1.00(0.98$ to 1.03$)$ \\
\hline Social allowance & & & $0.262^{* * *}(0.057)$ & $1.30(1.16$ to 1.46$)$ & $0.263^{* * *}(0.057)$ & $1.30(1.16$ to 1.46$)$ \\
\hline Population density & & & & & $0.093(0.214)$ & $1.20(0.96$ to 1.75$)$ \\
\hline \multicolumn{7}{|l|}{ Safety index } \\
\hline Many & & 1.00 & & 1.00 & & 1.00 \\
\hline Average & $0.179 * *(0.058)$ & 1.20 (1.06 to 1.35$)$ & $0.183^{* *}(0.056)$ & 1.20 (1.07 to 1.35$)$ & $0.176 * *(0.059)$ & $1.20(1.05$ to 1.36$)$ \\
\hline Few & $0.288^{* \star \star}(0.053)$ & 1.33 (1.19 to 1.50$)$ & $0.282^{* * *}(0.051)$ & 1.33 (1.19 to 1.48$)$ & $0.272^{* \star \star}(0.056)$ & 1.33 (1.15 to 1.49$)$ \\
\hline \multicolumn{7}{|c|}{ 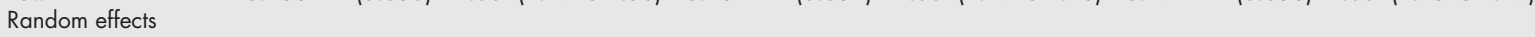 } \\
\hline Variance component & 0.00184 & & 0.00109 & & 0.00146 & \\
\hline AIC & 558.5 & & 474.8 & & 475.6 & \\
\hline
\end{tabular}

the municipalities in the remaining parts of Sweden. Thus, finding of a significant correlation between municipal safety measures and injuries, despite this homogeneity, indicates that the way different municipalities organise their safety activities in fact does affect the injury rates. These results would apply to other parts of Sweden. The injury rates in children are lower in Sweden than most other parts of Europe. ${ }^{27}$ That is probably because of more intense safety efforts in Sweden. Thus, the potential for municipal safety measures might be higher in other parts of Europe.

The negative correlation between safety measures and injury rates might be causal. A causal interpretation has to be based on the assumption that municipal safety measures are comparatively stable over several consecutive years. As it takes years to introduce safety routines, we think that the safety measures that were recorded in 1999-2001 reflected the level of municipal safety in 1994-1998. This assumption, however, was not tested. A causal interpretation has to rule out explanations by confounders. In our model, family social allowances and municipal population density were included as potential confounders. Family social allowance is a variable measuring poverty and as such, a proxy for socioeconomic position. ${ }^{28}$ If the use of inpatient care differs by socioeconomic groups in Sweden we would in this study have underestimated the injury risks among lower socioeconomic groups. However, a recent study could show that there is no such differential access to medical care in the Swedish health care system. $^{29}$

Introduction of these potential confounders into the model did not affect the relation between municipal safety measures and rates of injury. This finding indicates that community safety measures are quite independent of other municipality aspects. This makes explanation by confounding less probable.

Causality is best established by experiments. Yet, the experimental studies of community safety interventions that have been presented have included few control communities, often only one. ${ }^{7-9}$ Obviously, random variation might explain a more favourable development in one municipality when it is compared with another. This analysis, however, comprised 25 municipalities, making it possible to test an explanation by random variation between municipalities.

We have used hospital admission for injury as a proxy for injury. In this way only serious injuries are included, which is reasonable as safety measures aim mainly at preventing such injuries. Use of hospital admissions as proxy implies that all injuries of children residing in the county also are treated in hospitals in the county. This was usually true because children turning up at a hospital in another county would not be admitted unless they could not be transported safely to their county of residence. Factors other than injuries can affect admissions. One such factor is the distance to the hospital. However, in an analysis of children hospitalised in Stockholm County for injuries, these distances accounted for less than one per cent of the variation..$^{30}$ The data quality of the Hospital Discharge Registers can also be questioned. A validation of the Hospital Discharge Register conducted in 1996 showed a $3.75 \%$ drop out rate on the E-codes. ${ }^{13}$ As most injured children attend the only paediatric hospital in the region, it is not likely that this drop out is systematic with respect to municipality residency. However, the results in this study might be diluted

Table 8 Differences in injury outcome in 7-15 year olds, explained by factors at the municipality level and by individual characteristics

\begin{tabular}{|c|c|c|c|c|c|c|}
\hline & \multicolumn{2}{|l|}{ Model 1} & \multicolumn{2}{|l|}{ Model 2} & \multicolumn{2}{|l|}{ Model 3} \\
\hline & $\beta$ value (SE) & OR $(95 \% \mathrm{Cl})$ & $\beta$ value (SE) & OR $(95 \% \mathrm{Cl})$ & $\beta$ value (SE) & OR (95\% Cl) \\
\hline $\begin{array}{l}\text { Fixed effects } \\
\text { Intercept }\end{array}$ & $-5.516 * * *(0.085)$ & & $-5.526^{* * *}(0.084)$ & & $-5.536^{* * *}(0.086)$ & \\
\hline $\begin{array}{l}\text { Age } \\
\text { Social allowance } \\
\text { Population density } \\
\text { Safety index }\end{array}$ & $0.022 * *(0.006)$ & 1.02 (1.00 to 1.04$)$ & $\begin{array}{l}0.022 * *(0.007) \\
0.082(0.054)\end{array}$ & $\begin{array}{l}1.02(1.01 \text { to } 1.04) \\
1.090 .98 \text { to } 1.21)\end{array}$ & $\begin{array}{l}0.022^{* *}(0.007) \\
0.082(0.054) \\
0.185(0.219)\end{array}$ & $\begin{array}{l}1.02(1.01 \text { to } 1.04) \\
1.090 .95 \text { to } 1.21) \\
1.20(0.76 \text { to } 1.91)\end{array}$ \\
\hline Many & & 1.00 & & 1.00 & & 1.00 \\
\hline Average & $0.084(0.059)$ & 1.09 (0.96 to 1.23 ) & $0.083(0.060)$ & 1.09 (0.96 to 1.23 ) & $0.076(0.061)$ & 1.08 (0.95 to 1.23 ) \\
\hline $\begin{array}{l}\text { Few } \\
\text { Random effects }\end{array}$ & $0.081(0.058)$ & 1.09 (0.96 to 1.23 ) & $0.081(0.057)$ & 1.08 (0.96 to 1.23$)$ & $0.068(0.061)$ & 1.07 (0.94 to 1.22 ) \\
\hline Variance component & 0.00574 & & 0.00577 & & 0.00623 & \\
\hline $\mathrm{AIC}$ & 795.5 & & 765.3 & & 765.1 & \\
\hline
\end{tabular}


and thus the injury rates presented throughout might actually be higher.

The fact that the data are aggregated at the municipal level can also give rise to problems. Decisions on safety promotive measures in, for example, a preschool are made at the local level, and this means that preschool environments within a given municipality can vary considerably. Analysing data at a lower aggregation level, for example at a neighbourhood level, might have facilitated clearer correlations between safety measures and results. However, the registers used do not permit such analyses.

A strength of our study lies in our use of injury rates as outcome measures. Comparatively few published evaluations of community safety interventions have assessed variations in injury rates. ${ }^{7-9}$ Instead, self reported safety behaviours or changes in attitudes and knowledge have been studied as outcomes. Using injury rates as outcomes improve interpretations of community intervention effectiveness.

\section{Authors' affiliations}

E Sellström, Department of Nursing and Health Sciences, MidSweden University, Östersund, Sweden

K Guldbrandsson, Department of Public Health Sciences, Karolinska Institute, Stockholm, Sweden

S Bremberg, National Public Health Institute, Stockholm, Sweden A Hiern, Centre for Epidemiology, National Board on Health and Welfare, Stockholm, Sweden and Department of Women's and Children's Health, Uppsala University, Uppsala, Sweden G Arnoldsson, Department of Statistics, Umeå University, Umeå, Sweden

Funding: MidSweden University and a grant from Trygg-Hansa Research Foundation (D5/2002) funded this study.

Conflicts of interest: none declared.

\section{REFERENCES}

1 Guyer B, Gallagher S, Chang B, et al. Prevention of childhood injuries: evaluation of Statewide Childhood Injury Prevention Program (SCIPP). Am J Public Health 1989;79:1521-7.

2 Davidson L, Durkin M, Kuhn L, et al. The Impact of the Safe Kids Healthy Neighborhoods Injury Prevention Program in Harlem, 1988 through 1991. Am J Public Health 1994;84:580-6.

3 Svanström L, Ekman R, Schelp L, et al. The Lidköping Accident Prevention Programme - a community approach to preventing childhood injuries in Sweden. Inj Prev 1995:1:169-72.

4 Ozanne-Smith J, Day L, Stathakis V, et al. Controlled evaluation of a community based injury prevention program in Australia. Inj Prev 2002;8: 18-22

5 Lindqvist K, Timpka T, Schelp L, et al. Evaluation of a child safety program based on the WHO Safe Community Model. Inj Prev 2002;8:23-6.

6 Reference withdrawn.
7 Towner E, Dowswell T, Jarvis S. Updating the evidence. A systematic review of what works in preventing childhood unintentional injuries: part 1. Inj Prev 2001;7:161-4.

8 Klassen T, MacKay J, Moher D, et al. Community-based injury prevention interventions. Future Child 2000;10:83-1 10.

9 Towner E, Dowswell T. Community-based childhood injury prevention interventions: what works? Health Promotion Internation 2002;17:273-84.

10 Statistics Sweden. Total population register. Stockholm: Statistics Sweden, 1998

11 Swedish Board on Health and Welfare. The Swedish hospital discharge register. Stockholm: Swedish Board on Health and Welfare, 1999.

12 Swedish Board on Health and Welfare. International classification of diseases. Ninth revision (ICD-9). Stockholm: Swedish Board on Health and Welfare, 1986

13 Swedish Board on Health and Welfare. International statistical classification of diseases and related health problems, tenth revision (ICD-10). Stockholm: Swedish Board on Health and Welfare, 1997.

14 Statistics Sweden. The multi-generation register 2001:5. Stockholm: Statistics Sweden, 2001.

15 Statistics Sweden. The Swedish register of education. UF 37 SM 0101 Orebro: Statistics Sweden, 2001.

16 Swedish Board of Health and Welfare. Social assistance 1998. Stockholm: Swedish Board of Health and Welfare, 1998.

17 Statistics Sweden. Public statistics. Stockholm: Statistics Sweden, 2001 (www.web.scb.se)

18 Towner E, Simpson G, Jarvis S, et al. Unintentional injuries in young people. Effective Health Care 1996;2:1-16.

19 Munro P, Coleman J, Nicholl R, et al. Can we prevent accident injury to adolescents? A systematic review of the evidence. Inj Prev 1995; 1:249-55.

20 Dowswell T, Towner E, Simpson G, et al. Preventing childhood unintentional injuries - what works? A literature review. Inj Prev 1996:2:140-9.

21 Mölsted H, Andersson R, Hiern A, et al. Child safety in practice. A knowledge summary of evidence based injury prevention. Huddinge: Injury Prevention Unit, Child and Adolescent Public Health Unit, 1999.

22 Rivara F, Beahler M, Patterson D, et al. Systematic reviews of childhood injury prevention interventions. Washington: Harborview Injury Prevention Research Center, 2001. (http://depts.washington.edu/hiprc/ childinjury/)

23 Hosmer D, Lemeshow S. Applied logistic regression. Chichester: Wiley, 2000.

24 Leyland A, Goldstein H. Multilevel modelling of health statistics. Chichester: Wiley, 2001.

25 SAS Institute Inc. SAS/Stat manual version 8.02. Cary, NC: SAS Institute, 2001.

26 Lindsey J. Relationships among sample size, model selection and likelihood regions, and scientifically important differences. Journal of the Royal Statistical Society D 1999;48:401-12.

27 World Health Organisation. Children's health and environment: a review of evidence. Luxembourg: Office for Publications of the European Communities, 2002

28 Halleröd B. Poverty in Sweden. Report No 3. Stockholm: Swedish National Public Health Committee, Ministry of Health and Welfare, 1999.

29 Whitehead $M$, Evandrou $M$, Haglund $B$, et al. As the health divide widens in Sweden and Britain, what's happening to access to care? BM 1997;315:1006-9.

30 Alderling M, Onelov E. Distance, health indicators and health care consumption for children. [Master thesis]. Linköping: University of Linköping, 2000. 